\title{
Nursing Study Abroad: A New Perspective
}

\section{O'Hara PB*}

Gwynedd Mercy University, USA

*Corresponding author: Patricia Brown-O'Hara, Gwynedd Mercy University, 1325 sumneytown pike, USA, Tel: 2677182898; Email: brownohara.p@gmercyu.edu

\section{Editorial}

Volume 2 Issue 5

Received Date: October 26, 2018

Published Date: October 31, 2018

DOI: $10.23880 /$ nhij-16000161

\section{Abstract}

The impact of International Study Abroad has recently been studied. The data from more than 3,400 respondents shows that studying abroad is usually a defining moment in a person's life and continues to impact their life for years after the experience (IES Abroad Adelaide, 1992). Many nursing programs here in the United States do not have the flexibility in their nursing curriculum for study abroad, and the State Board of Nursing does not allow for nursing courses to be transferred in from other countries. This article will describe a Nursing Study Abroad program that was set up in Ireland for 3 weeks. Nursing students in this 4 year Traditional BSN program were able to obtain 6 credits (3 credits for their English Elective and 3 credits for their Nursing Elective) as well as experience 2 clinical observation days shadowing an Irish Public Health Nurse. A comprehensive description of the nursing study abroad program and the benefits associated with it will be provided.

\section{Introduction}

Qualitative research studies have highlighted the positive outcomes of study abroad programs. Qualitative themes such as "life changing", "lasting impact", "cultural identity" and "adventure" have been found in many of these studies.

Nursing programs often find it difficult to offer study abroad programs due to their strict nursing curriculum and stringent state board of nursing requirements. This article will highlight an innovative, study abroad program created for senior nursing students in a traditional, generic BSN program.

\section{Program Description}

After meeting with several Universities in Ireland, a four year University was selected for our nursing study abroad program. This University was selected for three reasons. First, this university was selected because they already had an existing, successful, summer non-nursing study abroad program in place where (100 to 200) American students attend classes for 3 weeks in the summer and earn 3 credits. The 3 credits earned can be in English, Literature and Fine Arts, Business, and Self- care. Students attend classes for 3 weeks, 4 days/week, (10:00AM -12:00 and 2:00-4:00 PM). On the $5^{\text {th }}$ day each week, a class trip is held and students go on a faculty led excursion to Dublin, Limerick and the Cliffs of Moher. Tuition for this program is very reasonable ( $\$ 2800$ Euros) and includes the 3 transferable credits, on-campus housing for all 3 weeks, food Monday through Friday, the 3 class trips, busing to and from the airport and social events. Students have their own free time on weekends to explore the country of Ireland. 


\section{Nursing \& Healthcare International Journal}

The second reason this University was chosen is because the International Study Abroad Office and the University's nursing faculty were willing to set up 2 clinical observation days for our nursing students in Community Health > Our 3 credit Nursing Elective is now being used on this trip. One of our Community Health faculty members accompanies the students and oversees this elective, entitled, "Community Health Nursing in Ireland". This course contains 7 Course Learning Outcomes which are met by the students in Ireland:

1. Describe the characteristics of community health nursing in Ireland

2. Examine Ireland's Community Health Nursing Models and their impact on clients in the community

3. Evaluate and compare Ireland's nursing practice in the community, to ANA and Standards of Practice.

4. Examine the impact of Ireland's health care delivery system on the continuum of care

5. Assess factors that affect family health and the impact on individuals, families and aggregates in the Irish community.

6. Examine ethical, legal, and sociocultural issues related to community health nursing practice in Ireland.

7. Demonstrate professional behavior in all settings.

These course learning outcomes are met by conducting a literature review and reading current literature on Community Health Nursing in Ireland, clinical shadowing of a Community health Nurse, and seminar discussions. Evaluation methods for this course consist of class discussion (20\%), Clinical Journaling (20\%), and a Community Health Nursing Comparison Paper (60\%). All grading is done by our own Community Health Nursing faculty member and the credits are earned through our own university.

Lastly, this Irish University was chosen because the nursing faculty who teach at the Irish University were willing to do some lecturing/discussion seminars with our students. These lectures as well as the discussion seminars are held 2-3 evenings/week during the students' stay in Ireland. The clinical shadowing is held on 2 of the bank holidays when the Irish University is closed.

\section{Summary}

Study abroad programs can be very successful and have a lasting impact on a students' professional and personal life. Nursing programs can develop successful programs if they are creative and find an International partner willing to work with them. Our next goal is to continue the work in nursing research by validating our experiences, and collaboratively writing about and sharing our stories both individually and collectively.

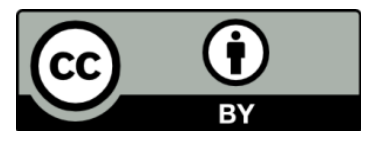

